(creatinine concentration $50-110 \mu \mathrm{mol} / 1 ; 0.6-1 \cdot 2 \mathrm{mg} / 100 \mathrm{ml}$ ) for whom histological findings were available before and immediately after the pregnancy.

In the early onset group eight of the 10 multiparas with IgA disease had suffered pre-eclampsia in previous pregnancies. After these earlier pregnancies they had become normotensive but phase contrast microscopy had not been performed. The presence of appreciable microscopic haematuria in subsequent pregnancies suggests that their previous episodes of pre-eclampsia were very likely related to IgA disease.

In 25 patients with IgA nephropathy 21 did not have appreciable proteinuria post partum and only five continued to be hypertensive, while renal function was normal in all. This emphasises that normal renal function and absence of proteinuria post partum do not exclude underlying renal disease in women with recurrent or early onset pre-eclampsia.

Not all patients with IgA nephropathy who become pregnant, however, are destined to develop pre-eclampsia. Our patients were selected because of problems related to pregnancy. Katz et al found a low incidence of pre-eclampsia in women with known kidney disease. ${ }^{8}$ Nevertheless, a previous study suggested that the presence of IgA nephropathy and pre-eclampsia has a high association, with $62 \%$ of pregnancies complicated by this condition.' Again, however, these patients were referred only because of problems related to pregnancy.

We were surprised by biopsy findings consistent with diabetic nephropathy in the three patients who had gestational diabetes, since one had required insulin during pregnancy to maintain normoglycaemia. Gonzalez-Gonzalez et al reported similar findings in eight women with mild diabetes in pregnancy, four of whom developed pre-eclampsia.' All eight had biopsy changes consistent with diabetic nephropathy.

This study has shown that a presumptive diagnosis of true or idiopathic pre-eclampsia is likely to be correct only in primiparas who develop the signs late in pregnancy. In all others a careful search for an underlying medical disorder has a high probability of yielding a positive finding, as shown by a $90 \%$ prevalence of causative disease (roughly two thirds renal) in this short term follow up investigation. Multiparous patients with pre-eclampsia (early or late) should also always be thoroughly investigated. Pre-eclampsia should not be taken as a final diagnosis. It is a pregnancy related syndrome only in the small group with a late onset (greater than 37 weeks of gestation).

Definitive diagnosis enables a more informed prognosis to be given for future pregnancies. Nevertheless, reliance on only biochemical indices of renal function in order to detect renal impairment will underestimate the presence of chronic renal disease; careful phase contrast microscopy should therefore be carried out, which is cheap and a very useful screening test with a high sensitivity and specificity and no false positivity. This simple test also allows confident selection of patients who might be considered for renal biopsy.

\section{References}

1 Fairley KF, Birch DF. Haematuria: a simple method for identifying glomerular bleeding. Kidney Int 1982;21:105-8.

2 Long PA, Abell DA, Reischer NA. Fetal growth and placental function assessed by urinary estriol excretion before the onset of pre-eclampsia. Am $\mathcal{O}$ Obstet Gynecol 1979;135:344-7.

$3 \mathrm{Lim}$ CH, Woo KT, Pwee HS, Edmonson RPS, Chaing GSC. The results of screening for proteinuria and microscopic haematuria on 16 year old national service registrants. In: Becker GJ, Atkins RC, Kincaid-Smith P, eds. Proceedings of 2 nd Asian Pacific congress of nephrology. Maryborough: The Dominion Press-Hedges and Bell, 1984:175-82.

4 Disney APS, Sheil AGR, eds. Seventh report of the Australian and New Zealand combined dialysis and transplant registry. Woodville: Queen Elizabeth Hospital and Australian Kidney Foundation,
tisney APS, Sheil AGR, eds. Seventh report of the Australian and New Zealand combined dialysis and 1984

5 Nicholls KM, Fairley KF, Dowling JP, Kincaid-Smith P. The clinical course of mesangial IgA associated nephropathy in adults. $Q \mathcal{J}$ Med 1984;210:227-50

6 Kincaid-Smith P. Mesangial IgA nephropathy. BrMed J 1985;290:96-7.

7 Kincaid-Smith PS, Whitworth J, Fairley KF. Mesangial IgA nephropathy in pregnancy. Clin Exp Hypertens 1980;2:821-38.

$8 \mathrm{Katz}$ AI, Davison JM, Hayslett JP, Singson E, Lindheimer MD. Pregnancy in women with kidney disease. Kidney Int 1980;18:192-200.

9 Gonzalez-Gonzalez L, Lopez-Llera M, Gonzalez-Angulo A, Linares GR, Sneider GB. Diabetes mellitus and toxemia of pregnancy: electron microscopic study of renal biopsies. $\mathcal{I}$ Reprod Med 1971;7:133-8.

(Accepted 8October 1986)

\title{
Life threatening sickle chest syndrome treated with extracorporeal membrane oxygenation
}

\author{
D S GILLETT, K E J GUNNING, E H SAWICKA， A J BELLINGHAM， R J WARE
}

\begin{abstract}
A young West Indian woman with established sickle cell disease developed a severe episode of sickle chest syndrome. Conventional treatment including exchange transfusions and mechanical ventilation was to no avail, and an infusion of epoprostenol also failed to halt her worsening condition. When her arterial oxygen tension $\left(\mathrm{PaO}_{2}\right)$ had fallen to $6.5 \mathrm{kPa}$
\end{abstract}

King's College Hospital, London SE5

D S GILLETT, MRCP, MRCPATH, lecturer and honorary senior registrar in haematology

K E J GUNNING, FRCS, FFARCS, registrar in anaesthesia

E H SAWICKA, MD, MRCP, senior registrar in thoracic medicine

A J BELLINGHAM, FRCP, professor of haematology

R J WARE, FFARCS, consultant anaesthetist and director of intensive care unit

Correspondence to: Dr Sawicka.
$(49 \mathrm{~mm} \mathrm{Hg}$ ) extracorporeal membrane oxygenation was instituted.

Within two days her $\mathrm{PaO}_{2}$ was greatly improved (maximum 11.6 $\mathrm{kPa} ; 87 \mathrm{~mm} \mathrm{Hg}$ ), and by the sixth day pulmonary vascular resistance was reduced and angiography showed reperfusion of many vessels. The patient recovered and six months later showed a transfer factor close to the predicted range and normal spirometric values.

Extracorporeal membrane oxygenation should be considered for severe sickle chest syndrome when conventional methods of artificial ventilation fail.

\section{Introduction}

Sickle chest syndrome is a common complication of sickle cell disease, presenting with chest pain, fever, and leucocytosis. The pathophysiology is uncertain, and some patients become progressively hypoxic and die despite conventional management and 
intermittent positive pressure ventilation. ${ }^{1}$ We present a case in which oxygenation was maintained with extracorporeal membrane oxygenation, which allowed the pulmonary changes to resolve.

\section{Case report}

A 20 year old West Indian woman with known haemoglobin sickle cell disease presented with pain in the chest, back, and right leg. Two days after admission she developed a fever of $38.5^{\circ} \mathrm{C}$ and tachypnoea. Amoxycillin and exchange transfusions were begun, but by the fifth day she had deteriorated with persistent fever and purulent sputum. She was cyanosed, widespread crackles and wheezes were heard throughout the chest, and a radiograph showed bilateral patchy consolidation. Results of investigations were: haemoglobin concentration $105 \mathrm{~g} / \mathrm{l}$, white cell count $7 \cdot 3 \times 10^{9} / 1$, platelet count $46 \times 10^{9} / 1$, concentration of fibrin degradation products $128 \mu \mathrm{g} / 1$, and prothrombin time 15 seconds (control 14).

Thrombocytopenia with numerous blister cells on the blood film and negative sputum culture supported a diagnosis of sickle chest syndrome rather than infection. Haemoglobin S and haemoglobin C accounted for $35 \%$ of total haemoglobin and were subsequently maintained at less than $20 \%$ with frequent transfusions. By the seventh day the arterial oxygen tension $\left(\mathrm{PaO}_{2}\right)$ had fallen to $7 \cdot 3 \mathrm{kPa}(55 \mathrm{~mm} \mathrm{Hg})$ (fraction of inspired oxygen $\left(\mathrm{F}_{1} \mathrm{O}_{2}\right)$ 0.6) and mechanical ventilation was initiated. Escherichia coli was isolated from blood cultures and the patient treated with amikacin and cefuroxime. $\mathrm{PaO}_{2}$ deteriorated despite ventilation with $12 \mathrm{~cm} \mathrm{H} \mathrm{H}_{2} \mathrm{O}$ positive end expiratory pressure, an $\mathrm{F}_{\mathrm{I}} \mathrm{O}_{2}$ of 0.5 , and a peak inflation pressure of $60 \mathrm{~cm} \mathrm{H}_{2} \mathrm{O}$.

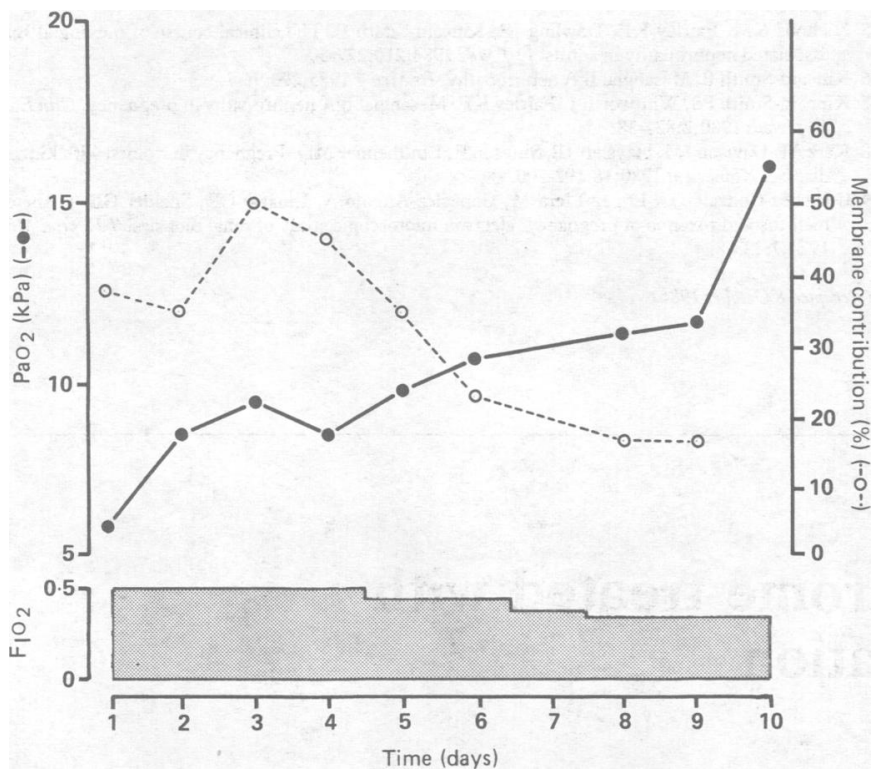

Mean daily arterial oxygen tensions $\left(\mathrm{PaO}_{2}\right)$, fraction of inspired oxygen $\left(\mathrm{Fr}_{\mathrm{r}} \mathrm{O}_{2}\right)$, and contribution of membrane to oxygen delivery during 10 days of extracorporeal membrane oxygenation.

Conversion: SI to traditional units- $\mathrm{PaO}_{2}: 1 \mathrm{kPa} \approx 7 \cdot 5 \mathrm{~mm} \mathrm{Hg}$.

Pulmonary vascular resistance reached a maximum of $1132 \mathrm{dyn} / \mathrm{s} / \mathrm{cm}^{5}$ (normal 50-150) with a pulmonary artery pressure of $50 / 35 \mathrm{~mm} \mathrm{Hg}$ and a low wedge pressure. A limited pulmonary angiogram showed severe pruning of the vascular tree. Infusion of epoprostenol $(\leqslant 15 \mathrm{ng} / \mathrm{kg} / \mathrm{min})$ produced no improvement, and when the $\mathrm{PaO}_{2}$ had fallen to $6.5 \mathrm{kPa}(49 \mathrm{~mm} \mathrm{Hg})\left(\mathrm{F}_{\mathrm{I}} \mathrm{O}_{2}\right.$ 1.0) extracorporeal membrane oxygenation was begun.

Blood from the right femoral vein was passed through a Scimed 2 membrane oxygenator at $1 \cdot 5-2.0 \mathrm{l} / \mathrm{min}$ using a Centrimed pump and returned with an oxygen tension of $88 \mathrm{kPa}(662 \mathrm{~mm} \mathrm{Hg})$ through the right internal jugular vein. Oxygen consumption was reduced by core cooling to $34^{\circ} \mathrm{C}$. Over two days the $\mathrm{PaO}_{2}$ had risen to a maximum of $11.6 \mathrm{kPa}(87$ $\mathrm{mm} \mathrm{Hg}$ ) and the arterial carbon dioxide tension had fallen to $4.8 \mathrm{kPa}(36$ $\mathrm{mm} \mathrm{Hg}$ ), allowing reduction in inflation pressure, positive end expiratory pressure, and $\mathrm{F}_{1} \mathrm{O}_{2}$. At six days the pulmonary artery pressure had fallen to $44 / 20 \mathrm{~mm} \mathrm{Hg}$ and a repeat angiogram showed reperfusion of many of the vessels. Thereafter the patient's pulmonary condition improved (figure), and extracorporeal membrane oxygenation was discontinued after 10 days. Though her recovery was complicated by candidal septicaemia, her chest radiograph showed gradual improvement and she was eventually discharged home. Six months later tests of pulmonary function showed a reduction in transfer factor to $6.32 \mathrm{mmol} / \mathrm{min} / \mathrm{kPa}$ (predicted 6.96-9.76) $(18.9 \mathrm{ml} / \mathrm{min} /$ $\mathrm{mm} \mathrm{Hg}$, predicted $20 \cdot 8-29 \cdot 2)$ and spirometric values were normal.

\section{Discussion}

Treatment with extracorporeal membrane oxygenation has not $\mathbb{E}$ improved the mortality of severe respiratory failure from other causes. ${ }^{2}$ The pathophysiology of the sickle chest syndrome remains obscure but infective agents are probably not implicated. Postmortem studies have described alveolar necrosis, bone marrow emboli, and patchy infarction without identifiable thromboses.$^{34}$ In a recent survey of 25 episodes, two of which were fatal, Davies et al suggested that intravascular sickling may account for the falls in haemoglobin concentration and platelet count seen in severe cases. ${ }^{1}$

In our patient an infective agent was isolated only in the later stages, and despite prompt exchange transfusion and appropriate $\vec{\circ}$ antibiotics her condition deteriorated. Widespread sickling with consequent occlusion of distal pulmonary vessels would explain the angiographic findings and the concomitant severe pulmonary artery hypertension. Exchange transfusion usually produces prompt 3 improvement in the sickle chest syndrome, but in other cases the prognosis has hitherto been grave. Adequate prepulmonary oxygenation with an extracorporeal membrane oxygenator of produced an immediate fall in pulmonary vascular resistance with $\$$ clinical, functional, and radiological improvement. Subsequent $\stackrel{\infty}{\rightarrow}$ pulmonary function tests showed that the condition is reversible. We suggest that this method of treatment should be considered in the management of severe sickle chest syndrome when standard methods of artificial ventilation fail.

We thank Mr A Pastellopoulos and the cardiopulmonary technical staff who managed the membrane oxygenation.

\section{References}

1 Davies SC, Luce PJ, Win AA, Riordan PJ, Brozovic M. Acute chest syndrome in sickle-cell disease. Lancet 1984;i:36-8.

2 Zapol WM, Snider MT, Hill JD, et al. Extracorporeal membrane oxygenation in severe acute respiratory failure. JAMA 1979;242:2193-6.

3 Athanasou NA, Hatton C, McGee OD, Weatherall DJ. Vascular occlusion and infarction in sickle cell crisis and the sickle chest syndrome. J Clin Pathol 1985;38:659-64.

4 Haupt HE, Morre GW, Bauer TW, Hitchins GM. The lung in sickle chest disease. Chest 1982;81:332-7.

(Accepted 10 October 1986)

\section{YEARS AGO}

English people, and especially English builders, having been taught in their youth that England has a temperate climate, always proceed on the assumption that few, if any, precautions are required against the effect of $N$ excessive heat and cold. As a consequence of this ignorance or obstinacy, our houses are constructed in a way so ill adapted for either extreme of $\sigma$ temperature, that while Parsees are prostrated by the heat in summer, our Russian visitors find the cold of an English winter unbearable. The walls are not made thicker than the narrowest margin of safety will allow; the windowsashes are ill-fitting, and the glass is thin. The Venetian blinds are placed inside, where they are useless, instead of outside, where they are really serviceable. We should be glad to see, in the new houses which are springing up all over London, the wooden persiennes which are so characteristic a feature of house-fronts abroad. Like the Spanish beggar's cloak, they keep out the heat in summer and keep it in in winter. Unfortunately buildersand architects, for the matter of that-are a stiff-necked generation, and look upon these and kindred improvements as the typical John Bull regards "foreign kickshaws." The tenant has therefore no resource but to mitigate the horrors of our "temperate" climate as best he can at his own expense. (British Medical Fournal 1887;ii:94.) 